\title{
Recent developments in mitochondrial medicine (Part 1)
}

\author{
Volkmar Weissig ${ }^{1, *}$ and Marvin Edeas ${ }^{2,3}$ \\ ${ }^{1}$ Midwestern University, College of Pharmacy, Department of Pharmaceutical Sciences, 19555 N. 59th Avenue, \\ Glendale, AZ 85308, USA \\ ${ }^{2}$ Université de Paris, INSERM U1016, Institut Cochin, CNRS UMR8104, Faculté de médecine Cochin-Port Royal, \\ 75014 Paris, France \\ ${ }^{3}$ Laboratory of Excellence GR-Ex, 75015 Paris, France
}

Received 15 February 2021, Accepted 15 April 2021

\begin{abstract}
Research into elucidating structure and function of mitochondria has been quite steady between the time of discovery during the end of the 19th century until towards the late 1980's. During the 1990s there was talk about a "comeback" of this organelle reflecting a widely revitalized interest into mitochondrial research which was based on two major discoveries made during that time. The first was the etiological association between human diseases and mitochondrial DNA mutations, while the second revealed the crucial function of mitochondria during apoptosis. The March 5th, 1999 issue of Science even featured a textbook image of a mitochondrion on its front cover and was entirely dedicated to this organelle. Whilst the term "comeback" might have been appropriate to describe the general excitement surrounding the new mitochondrial discoveries made during the 1990s, a term for describing the progress made in mitochondrial research during the last two decades is difficult to find. Between 2000 and 2020 the number of publications on mitochondria has skyrocketed. It is now widely accepted that there hardly exists any human disease for which either the etiology or pathogenesis does not seem to be associated with mitochondrial malfunction. In this review we will discuss and follow several lines of mitochondrial research from their early beginnings up to the present. We hope to be able to convince the reader of what we expressed about a decade ago, that the future of medicine will come through mitochondria.
\end{abstract}

Keywords: Biochemistry, Cells, DQAsome, Lipoplexe, Heteroplasmy, miRNA, Mitochondrial medicine, Mitochondrial diseases, Mitochondrial DNA, Mitochondrial dysfunction, Mitochondrial research, Mitochondrion, Mitochondrium, mitomiRs, mtDNA, Organelle, Physiology, PNA, Research, Science

\section{Introduction}

All human cells, except erythrocytes, harbor mitochondria in the form of a tubular network constantly undergoing fission and fusion. Known as the "powerhouse of the cell", they are at the juncture of energy-producing pathways, as the "cell's arsenal" they play a decisive role in programmed cell death (apoptosis). In addition, mitochondria are involved in a multitude of anabolic, catabolic, and signaling pathways.

According to the endosymbiotic theory mitochondria are descended from once free-living bacteria which were engulfed by prokaryotic cells. This today generally accepted evolutionary theory was proposed for the first time in 1966 by Lynn (Sagan) Margulis who had, as she remembers [1], to submit her corresponding manuscript to about 15 different journals before it was accepted by the Journal of Theoretical Biology [2].

*Corresponding author: vweiss@midwestern.edu
Mitochondria contain their own DNA and as shown by Doug Wallace and his group in 1980 [3] are maternally inherited. A recently claimed biparental inheritance of mitochondria in humans [4] however has triggered some contentious discussions [5, 6]. Based on correlating mitochondrial DNA (mtDNA) variations between populations from around the world Wallace was able to reconstruct origin and migration patterns of women in ancient times, which gave rise to the speculation about a "Mitochondrial Eve" the most recent female from whom all humans might have descended.

Mitochondrial DNA encodes for 13 polypeptides essential for energy production; all other mitochondrial proteins encoded by nuclear DNA are imported from the cytoplasm. The amount of mitochondrial mass per cell organized as a sub-micro- to nano-structured tubular network extending three-dimensionally around the nucleus and throughout the cytoplasm depends on the energy demands of the cell. Organs with the highest energy consumption are the brain, skeletal muscle, the kidney cortex, liver, heart and the 
visual system. Though mitochondrial malfunction as the cause of human disease was described for the first time in 1962 [7], the genetic basis for mitochondrial diseases remained elusive until 1988 [8]. Subsequent research over the last three decades has revealed that there is hardly any human disease the etiology or pathogenesis of which is not associated with mitochondrial malfunction, a realization leading us [Marvin Edeas and Volkmar Weissig (ME \& VW)] to conclude that "the future of medicine will come through mitochondria" [9].

In this review, written for "non-mitochondriologists", we outline about 170 years of mitochondrial research whilst emphasizing the major groundbreaking discoveries and developments made since the beginning of the new century. Because we (ME \& VW) have been hosting in Berlin (Germany) the Annual World Conference on Targeting Mitochondria since 2010 (the 12th edition will take place in October 2021), we are fortunate to know on a personal level many of the major investigators who are pushing mitochondrial research forward. In this review, we highlight their contributions to the field of mitochondrial medicine.

\section{From "thread-like granules" to "cristae junctions"}

Studies using light microscopy on cells during the second half of the 19th century uncovered the existence of small subcellular granules [10] which in shape and size were similar to bacteria as observed by Richard Altmann (18521900) who named them "bioblasts" in $1890[10,11]$. Based on the Greek, eight years later, Carl Benda (1857-1932) coined the term "mitochondria" in 1898 [12], with "mitos" meaning thread and "chondrion" meaning grain. Noteworthy, although obviously already recognized at the end of the 19th century, the thread-like morphology of mitochondria only became fully appreciated at the beginning of the 21st century when it was revealed that the maintenance of the tubular (thread-like) network characteristic of mitochondria is critical for human health [13-15]. The appearance of mitochondria as individual objects usually indicates a severely damaged mitochondrial network as present in unhealthy, dying cells or as an artifact of sample processing for microscopic images. Unfortunately, the depiction of mitochondria in text books as single bean-like shaped bodies seems to be still very common.

By 1930, most cytologists had recognized mitochondria as well-defined and ubiquitous cellular structures, but there was no agreement as to their function. In 1890, Richard Altmann proposed them to be the basic units of cellular activity, other proposals made suggested them to be the center for genetic information, protein synthesis, respiration and lipid synthesis [10].

The average single mitochondrion, disconnected from the tubular mitochondrial network by fixation and staining procedures of tissues samples, appears as a bean-shaped organelle with approximately the size of Escherichia coli, up to $2 \mu \mathrm{m}$ long and $1 \mu \mathrm{m}$ wide, i.e. it is large enough to be visible under the light microscope. Light microscopy however does not allow for a more detailed structural analysis of mitochondria.

Their major structural features, which are an outer membrane and a highly convoluted inner membrane, were made visible for the first time during the early 1950's when George Emil Palade (1912-2008, Nobel Prize Physiology 1974) investigated the organelle under the electron microscope [16, 17]. Based on Palade's work a model for the inner structure of mitochondria was developed which dominated the literature for up to 50 years (Fig. 1A). According to this model, mitochondria have two aqueous sub compartments, the intermembrane space (IMS) between the outer and the inner membrane and the so-called mitochondrial matrix. Here it should be noted that although the term "aqueous sub compartments" is still widely used, it is misleading. Due to the presence of between 1100 and 1400 [18] distinct proteins, the mitochondrial matrix "constitutes a biochemical reaction environment with a highly complex structure" [19]. The viscosity of the mitochondrial matrix solvent has been determined to be between 2.69 and $3.32 \mathrm{cP}$, which can, under a variety of physiological and pathological conditions increase up to 30-fold [19]. For comparison, the viscosity of water is about $1 \mathrm{cP}$.

In Palade's model no barrier exists between the space inside the cristae and the IMS. This model became obsolete towards the end of the 1990's when Perkins and Frey investigated mitochondrial morphology by electron microscope tomography $[20,21]$ and discovered junctions at the neck of cristae (Fig. 1B). Due to their narrow diameter of about $12-40 \mathrm{~nm}$, these junctions were proposed to impede the flow of proteins and metabolites towards and away from cristae thereby creating an aqueous compartment distinct from the IMS and also separated from the mitochondrial matrix.

Studies conducted during the last decade, [22] have revealed major protein complexes which control the formation of cristae and their junctions, among them optic atrophy 1 protein (OPA1) and the mitochondrial contact site and cristae organization system (MICOS) (Fig. 1B).

Controlling cristae junctions is crucial for mitochondrial function. In the mid-1960s, Charles Hackenbrock reported that ultrastructural changes of mitochondrial cristae were associated with metabolic changes [23-25]. In 2002, Stanley Korsmeyer and co-workers showed that cristae remodeling is an essential step during a highly complex pathway leading to apoptosis (programmed cell death) [26]. Finally, a large body of work during the last 20 years (the reader is referred to an excellent recently published review [22]) revealed that malfunctioning cristae formation or cristae remodeling is associated with several human diseases. Just to name a few, mutations in the OPA1 gene have been linked to optic atrophy associated with deafness and dementia, as well as encephalomyopathy, and cardiomyopathy (reviewed in [22]). Further studies about mitochondrial cristae formation will have "important implications for understanding human disease linked to various forms of mitochondrial dysfunction" [22]. 


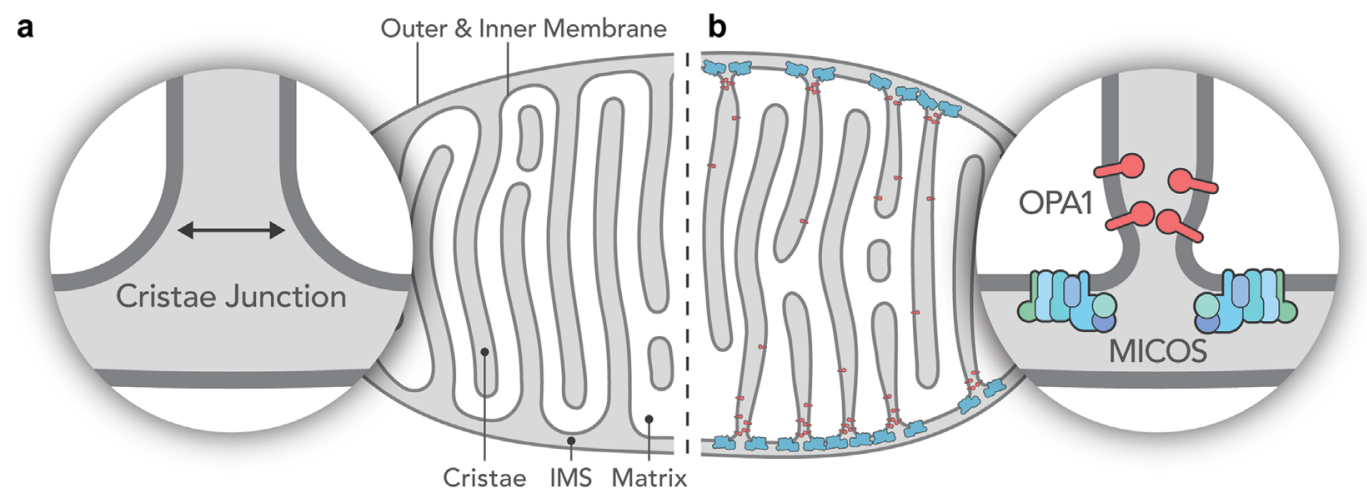

Figure 1. (A) The "old" and (B) the "new" model of the inner structure of mitochondria. Instead of the large openings connecting the intercristae space to the intermembrane space present in the old model (A), narrow tubular openings (crista junctions) connect these spaces in the new model (B) thereby creating a third aqueous intramitochondrial compartment. Panel (B) also shows the presence of two out of several protein complexes which control the formation and remodeling of the cristae junctions. This schematic illustration is based on figures in [22].

\section{From “Atmungsferment" to “Respirasomes"}

Exactly how substrates are being oxidized in aerobic organism was a hot topic discussion in the early 1900s. For example, Heinrich Otto Wieland (1877-1957, Nobel laureate in Chemistry in 1927) proposed that oxidation in living tissues involves the removal of the hydrogen atom (dehydrogenation) instead of the addition of oxygen [10]. Otto Warburg (1883-1970, Nobel Prize in Physiology or Medicine in 1931) advocated in 1914 for an iron compound, which he termed "Atmungsferment' ("Breathing Enzyme") as being the chief catalyst for activating and transferring oxygen in biological systems [27]. Subsequently, Warburg succeeded in identifying cytochrome oxidase as the enzyme that reacts with oxygen. In addition to finding the final cytochrome (cytochrome a3), Warburg also characterized nicotinamide adenine dinucleotide (NAD) as a hydrogen carrier in biological oxidation reactions. Interestingly, cytochromes were already described back in 1884 by Mac Munn as respiratory pigments that function in the transfer of oxygen [28]. Charles Alexander Mac Munn's (1852-1911) work however wasn't fully recognized and accepted until 40 years later when David Keilin (1887-1963) started in 1925 publishing a series of investigations about cytochrome systems of pigments in aerobic cells [29].

The next milestone towards revealing the secrets of biological oxidation and respiration was the description of the citric acid cycle or tricarboxyllic acid (TCA) or Krebs cycle by Sir Hans Adolf Krebs (1900-1981, Nobel Prize in Physiology or Medicine in 1953) in 1937 [30-34], who in turn built upon the earlier work by Albert Szent-Gyoergyi (18931986, Nobel Prize in Physiology or Medicine in 1937), Carl Martius (1906-1993) and Georg Franz Knoop (1875-1964) [7]. Hans Karl Heinrich Adolf Lohman (1898-1978) discovered ATP in 1929 [35] but its connection to and vital role in cell respiration wasn't established until 1937 [36]. Two years later Volodymyr Oleksandrovych Belitser (19061988) and Elena Tsibakova introduced the term "oxidative phosphorylation" [37] and about during the same time, between 1939 and 1941 Fritz Albert Lipmann (1899-1986, Nobel Prize in Physiology or Medicine in 1953) identified ATP as the main bearer of chemical energy in the cell, coining also the term "energy-rich phosphate bonds" [38-40].

Also during the 1940s, based on progress made in development of cell fractionation techniques, the activities of enzymes for fatty acid oxidation and the TCA cycle were found to be associated with mitochondrial fractions [10] and in 1953 Edward Charles Slater (1917-2016) proposed a scheme for the mechanism of oxidative phosphorylation involving chemical intermediates [41, 42]. These developments in mitochondrial research did not go unnoticed; the legendary term "Powerhouse of the cell" was coined in an article for Scientific American by Philip Siekevitz (19182009) in 1957 [43]. In 1961 it was suggested by Robert Joseph Paton Williams (1926-2015) that protons instead of Slater's energy-rich intermediates served to deliver energy to ATP synthase [44]. In the same year Peter Dennis Mitchell (1920-1992) postulated his chemiosmotic hypothesis [45-47] for which he was awarded the Nobel Prize in Chemistry in 1978. By and in 1962 the major players of the respiratory chain, i.e. enzymes with coenzymes, were purified, reconstituted and termed Complexes I-IV by Youssef Hatefi et al. [48-51] and by 1976 the fluid model of the inner mitochondrial membrane (IMM) organization was established [52, 53].

Since then it has become a widely believed dogma that all enzyme complexes, CI-CIV including the ATP synthase (Complex V) are independent diffusible proteins associated with the IMM and connected by small electron carriers shuttling between them. However, this paradigm of how the yeast and mammalian system of oxidative phosphorylation is organized fundamentally changed around 2000. Using a mild one-step protocol for the isolation of membrane protein complexes, namely blue-native polyacrylamide gel electrophoresis (BN-PAGE), Schragger et al were able to isolate supramolecular structures of the mitochondrial oxidative phosphorylation electron transfer chain (OXPHOS-ETC). They found that in mammalian mitochondria, almost all complex I is assembled into supercomplexes comprising 


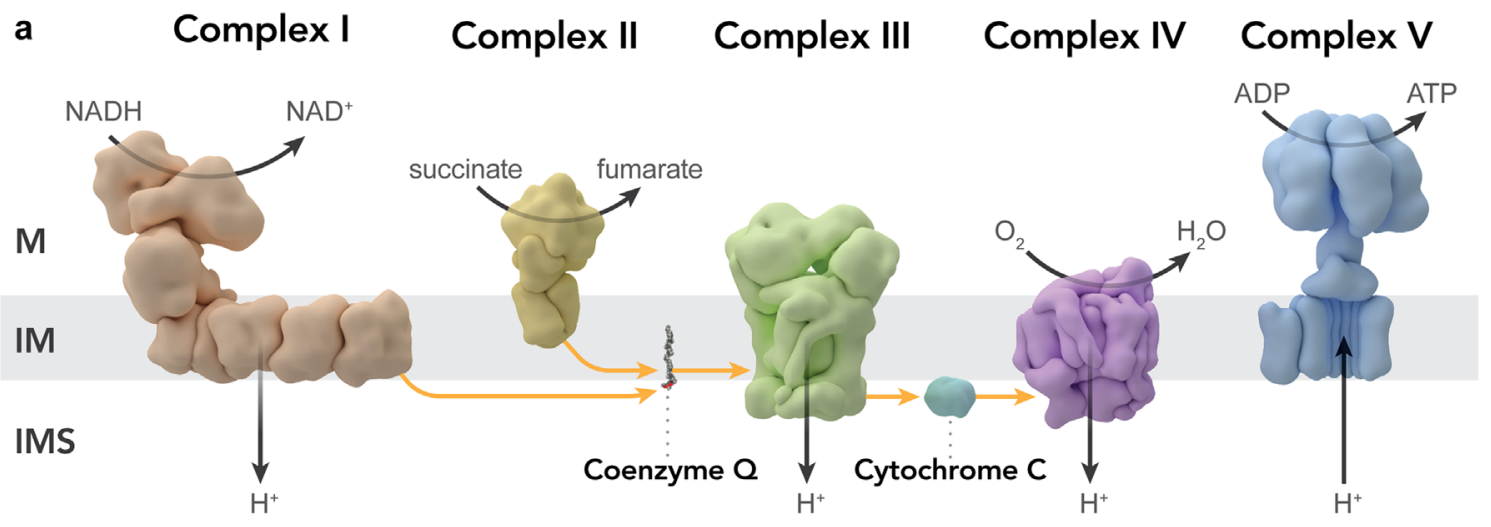

b

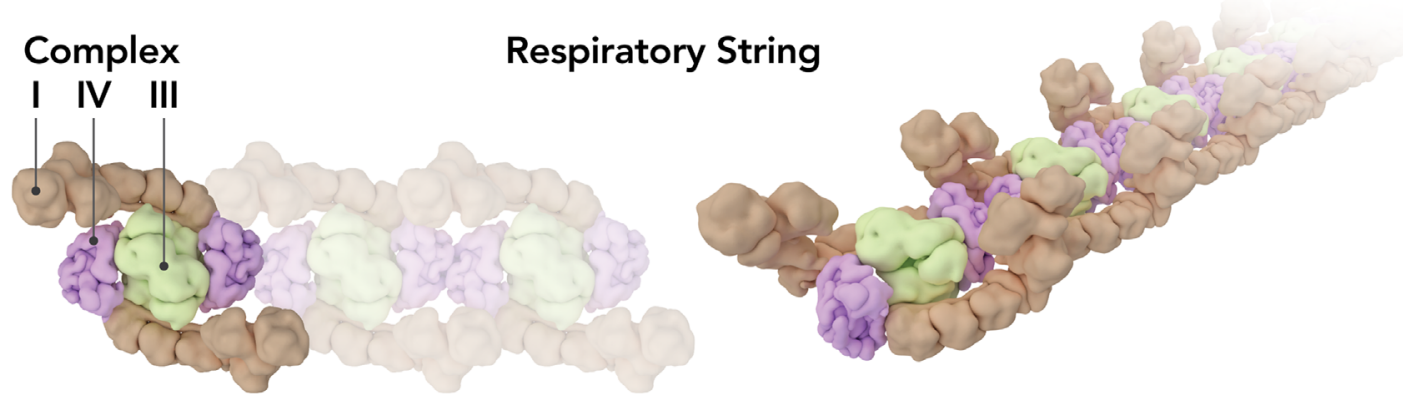

Figure 2. (A) "Classical" schematic representation of the mitochondrial oxidative phosphorylation (OXPHOS) system showing its individual components separated from each other, (M) matrix, (IMS) intermembrane space, (IM) inner membrane. (B) Schematic model of the organization of individual components of the respiratory chain (complexes I, III and IV) into a respiratory string. Both figure panels were created based on corresponding figures in [55].

complexes I and III and up to four copies of complex IV, which led the authors to propose a model for a network of respiratory chain complexes they named "respirasome" [54]. During the next 10 years (2000-2010) additional studies demonstrated that that complexes I and III in mammals and I, III, and IV in plants actually behave as single units kinetically, which led to the assumption of substrate channeling. Furthermore, recently it has been found that respirasomes seem to be organized into respiratory strings, as schematically shown in Figure 2 (reviewed in [55].

Finally, in 2016 the first detailed organization of a respirasome was published by Yang's group from Tsinghua University. The authors presented " $a$ 5.4 A cryo-electron microscopy structure of the major $1.7 \mathrm{MDa}$ SCI1IIIIVIV1 respirasome purified from porcine heart' [56]. Disruption of the formation of such supercomplexes or strings of respirasomes ultimately can cause OXPHOS malfunction resulting in pathologic changes [57]. Studying the detailed interactions within this huge molecular machinery will eventually provide important information for drug design and screening [58].

\section{The recognition of mitochondrial dysfunctions as a cause of human diseases}

Rolf Luft (1914-2007), a neurologist and endocrinologist at the Karolinska Institute in Sweden, discovered towards the end of the 1950s malfunctioning mitochondria as a cause of human diseases. In 1962, he published a paper entitled "A case of severe hypermetabolism of nonthyroid origin with a defect in the maintenance of mitochondrial respiratory control: a correlated clinical, biochemical, and morphological study" [7]. The ailment described in his paper, caused by an extensive uncoupling of mitochondrial respiration in skeletal muscle tissue, soon became known as "Luft disease". Rolf Luft is nowadays widely acknowledged as the "Father of Mitochondrial Medicine" and the Rolf Luft Foundation invites nominations for the "Rolf Luft Award in Diabetes and Endocrinology Research" each year. Luft's paper from 1962 spurred intense investigations into the possible role of mitochondria in the etiology of human disease. About 25 years later Hans Rudolf Scholte, in a comprehensive review of the biochemical basis of mitochondrial disease, was able to classify over 120 diseases. Luft himself wrote in 1994 "From Scholte's and subsequent reviews several basic principles in mitochondrial pathology emerged. First, some mitochondrial diseases affect only one tissue, most often skeletal muscle and brain but also liver, heart, kidneys or endocrine glands. Other organs may be involved secondarily. The disease may originate as a specific defect in mitochondrial function, but a variety of genetic and environmental factors may contribute to the phenotype" [59].

However, the genetic basis for mitochondrial diseases remained elusive until 1988 (see below). 


\section{The "Decade of the Mitochondrion"}

On March 5th in 1999 the editors of Science chose a textbook image of a mitochondrion as the front cover, which was unprecedented for this journal. It was a way for the Science editors to "officially" acknowledge the 1990s as the "decade of the mitochondrion". Two key discoveries were made during this decade: the first one actually continues where Luft and Scholte (see above) left off. Two papers, one in Science and the other one in Nature (both came out in 1988) revealed that mutations and deletions in mitochondrial DNA were associated with human diseases. Ian James Holt and co-workers described the link of deletion mutations of mitochondrial DNA (mtDNA) and mitochondrial myopathies [60], and Douglas Wallace and his team reported the association of Leber's Hereditary Optic Neuropathy (LHON) with mtDNA point mutations [8]. It should be noted that mitochondrial DNA was discovered back in 1963 by Nass \& Nass, who described "intramitochondrial fibers with DNA characteristics" [61] and was sequenced in 1981 [62]. Consequently, during the 1990's most of Luft's and Scholte's "classical" mitochondrial disorders were found to be linked to mtDNA mutations.

The second key discovery involves the crucial role of mitochondria during programmed cell death (apoptosis), which however we will not further discuss in this review. The interested reader is referred to a review from 2007 by Susan Elmore [63]. To highlight the excitement this key discovery has triggered, we would like to cite what Brown, Nicholls ad Cooper, three key players in this field, wrote in 1999 in their preface to "Mitochondria and Cell Death" [64]:

"Who would have believed it?! Mitochondria, the powerhouses of cellular life, are also motors of cell death. Few would have accepted this even 5 years ago".

\section{Manipulation of the mitochondrial genome}

Finding an effective and reliable way to manipulate the mitochondrial genome has been the "Holy Grail" of mitochondrial medicine ever since defective mitochondrial DNA has been linked to human diseases. Due to the multi-copy nature of mtDNA, several principal strategies can be followed, which are correcting mtDNA mutations / deletions, selectively degrading mutated mtDNA circles, selectively inhibiting the replication of mutated mtDNA and replenishing mitochondria with wild-type copies of mtDNA (Fig. 3). All of these approaches have been and are still being explored since the 1990s and though all of them were and still are promising, the "hunt for the Holy Grail" is ongoing.

\section{Mitochondrial gene therapy}

Worldwide, during the 1990's over 1500 nuclear-targeted gene therapy trials have been conducted exploring a variety of nuclear-targeted viral and non-viral transfection vectors. Relating to a potentially similar approach towards mitochondria-targeted gene therapy, Peter Seibel wrote in 1995

"Successes in classical gene therapies have been achieved by placing a corrected copy of a defective nuclear gene in cells. A similar gene replacement approach for a mutant mitochondrial genome is invariably linked to the use of a yet unavailable mitochondrial transfection vector" [65].

Seibel's group launched the hunt for the "Holy Grail" by demonstrating that DNA coupled covalently to a short "mitochondrial leader peptide" can enter mitochondria via the protein import pathway, which at that time seemed to open a novel way for gene-, antisense-RNAor antisense-DNA-delivery for mitochondrial molecular therapies." [65]

A mitochondria-targeted transfection vector, in 1995 according to Seibel et al. still unavailable [65], presented itself during the same time when one of us (VW) discovered by chance that dequalinium chloride, a mitochondriotropic cationic bolaamphiphile, was able to self-assemble into cationic liposome-like vesicles, named "DQAsomes" (DeQAlinium-based liposomes) $[66,67]$. Liposomes are man-made vesicles between 50 and $1000 \mathrm{~nm}$ in diameter in which one or more phospholipid bilayer membranes encapsulate an aqueous inner space. Following the synthesis of cationic phospholipid derivatives in 1987 by Phillip Felgner's group [68], liposomes could be rendered cationic which in turn enabled them to form complexes with negatively charged DNA. The striking similarity of DQAsomes with cationic liposomes widely used during the 1990s for nuclear-targeted gene therapy seemed to qualify DQAsomes as the mitochondrial transfection vector of choice [69, 70]. DQAsomes have been shown to meet all pre-requisites for a mitochondrial transfection vector, they bind and condense pDNA forming "DQAplexes", which are taken up by cells followed by their early endosomal release (just like it is known from cationic liposome/DNA complexes aka "Lipoplexes") and upon contact with mitochondrial membranes DQAplexes become destabilized releasing a portion of the DNA from its cationic carrier [71-74].

Finally, it was demonstrated that oligonucleotides as well as plasmid DNA conjugated to a mitochondrial leader sequence co-localize with mitochondria when delivered into mammalian cells via DQAsomes [75]. Yet the barrier lying between co-localization with mitochondrial membranes and functional DNA expression inside mitochondria proved to be unsurmountable at that time. However, several years later two groups have reported DQAsome-based transgene expression in mammalian mitochondria. In 2011, Lyrawati et al. described the expression of Green Fluorescence Protein (GFP) GFP in the mitochondrial compartment using DQAsome-mediated delivery of an artificial minimitochondrial genome [76] and Bae reported in 2017, an enhanced mitochondrial transfection efficiency in HeLa cells and dermal fibroblasts when using a modified DQAsome formulation called DQA80 [77]. Though both reports seem to be a promising start, despite their limitations as discussed most recently [78], any routine mitochondrial 


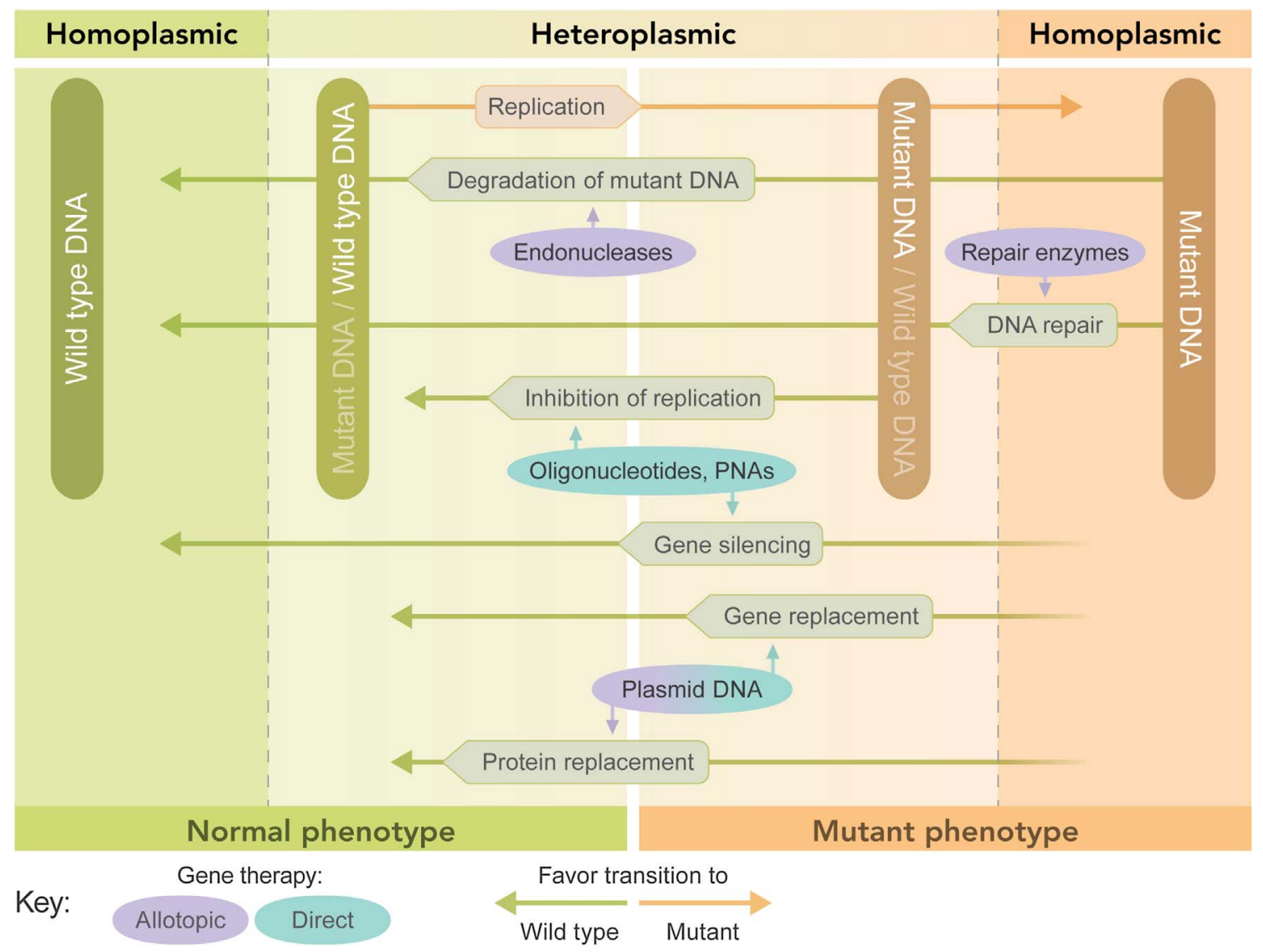

Figure 3. Graphical representation of the effect of various mitochondrial gene therapeutic approaches on mitochondrial heteroplasmy. A cell can go from homoplasmic wild type (dark Green) to homoplasmic mutant (dark ochre) and pass stages of heteroplasmy where either wild type (light green) or mutant (light ochre) mtDNA is dominant. The threshold determines the transition from normal phenotype to mutant phenotype. Ovals represent therapeutic intervention and rectangles represent natural processes. Arrows that do not contact the DNA boxes indicate that the process does not change the ratio or content of DNA. Figure recreated based on a corresponding figure in [145].

transgene expression in the laboratory and above all any mitochondrial gene therapy-based treatment of primary mitochondrial DNA diseases in the clinic have to be judged as being elusive. An alternative mitochondria-targeted nanocarrier, called Mito-Porter, has been designed by Hideyoshi Harashima's group. The Mito-Porter is a liposome-based carrier that delivers its macromolecular cargo to the mitochondrial interior via membrane fusion mediated by an octaarginine peptide (R8) on the liposome surface [79, 80]. More recently, in 2020, Harashima's group encapsulated wild-type mitochondrial pre-tRNA(Phe) into MITO-Porters and then transfected cells with mitochondria carrying a mutated version of tRNA (Phe). As result, the mutation rate of tRNA(Phe) was decreased, and this therapeutic effect was sustained even on the 8th day after transfection [81].

\section{RNA-based approaches towards the manipulation of the mitochondrial genome}

The majority of proteins functioning in mitochondria are imported from the cytoplasm and by the end of the 1990's the mechanism of mitochondrial protein import have been studied extensively [82-84]. In contrast to mitochondrial proteins imported from the cytoplasm, no imported tRNAs have been found inside mammalian mitochondria [85] though evidence had been presented for the transport of nuclear encoded tRNA into mitochondria in a variety of non-mammalian organism [86]. The mechanisms by which negatively charged RNAs can cross both hydrophobic mitochondrial membranes began to be unraveled in the late 1990's by Ivan Tarassov's group [87, 88]. During the last 20 years, a substantial amount of data has been accumulated demonstrating that in all eukaryotes noncoding RNAs are being transcribed from the nuclear genome followed by their transport into mitochondria, where they play a role in mitochondrial gene expression [89]. Today it has been well established that "the mitochondrial RNome represents an intricate mixture of the intrinsic transcriptome and the extrinsic RNA importome" [89] and efforts are aimed at exploring mitochondrially imported RNAs as a tool to further study mitochondrial DNA and pathologies associated with its malfunction. For example, exploiting the pathway of RNA import into mitochondria 
a recent study investigated the possibility of establishing a CRISPR-Cas9 system targeting mtDNA. Ivan Tarassov's group tested in vitro and in vivo mitochondrially targeted Cas9 versions and a set of mitochondria-specific guide RNAs regarding their effect on mtDNA copy numbers. The authors describe this system as "more complicated for use than previously found for nuclear DNA" and chose as title for their paper "Can Mitochondrial DNA be CRISPRized: Pro and Contra" [90].

\section{Shifting heteroplasmy}

Since mutations or deletions normally do not affect all mtDNAs, wild-type and mutated mtDNA can coexist in a cell, a phenomenon called heteroplasmy. Depending on the cell type, in particular on the cell's energy demand, a minimal number of mtDNA circles have to be damaged to cause clinical symptoms, which is called the threshold effect. Shifting the level of heteroplasmy by selectively inhibiting the replication of the mutant mtDNA and thereby allowing propagation of only the wild-type molecule was proposed for the first time in 1997 by Robert Lightowlers group in Newcastle, UK [91]. To confirm the validity of such a novel strategy they synthesized peptide nucleic acids (PNAs) complementary to human mtDNA templates containing certain mutations known to cause human pathologies. Using an in vitro replication run-off assay under physiological conditions, the authors confirmed that their antigenomic PNAs specifically inhibited replication of mutant but not wild-type mtDNA templates [91]. Following Lightowlers' pioneering work, designing ways to manipulate heteroplasmy in cells became a hot area of research for the next 20 years, "but until recently, a viable method has proven elusive" [92]. Most recent efforts towards the selective degradation of mutated mtDNA involve zincfinger nucleases (ZFNs) [93] and transcription activator-like effector nuclease (TALENS) [94, 95], both of which are enzymes able to selectively target single nucleotide mutations. Both enzymes have genetically been modified to express at their $\mathrm{N}$ termini a mitochondrial leader peptide to ensure their transport into the mitochondrial matrix and both enzymes have recently been successfully tested in mice carrying a heteroplasmic pathogenic variant in mt-tRNA $^{\text {Ala }}[94,95]$. Both enzymes are introduced into cells via nuclear-targeted transfection using viral vectors, and the remaining problem is the crossing of the BBB by the vector, which is of importance considering that neurodegenerative diseases have been linked to mtDNA mutations / deletions within the CNS [92].

\section{Bypassing manipulating of the mitochondrial genome via allotopic expression}

In contrast to the above described direct mitochondrial gene therapy this approach involves the nuclear-cytosolic expression of a protein originally encoded by mtDNA now mutated and ensuring its transport into the mitochondria matrix by utilizing mitochondrial leader peptides recognized by the mitochondrial protein import machinery.
Limited success of allotopically expressing mitochondrial genes was described for the first time in yeast in 1988 [96, 97], endorsed for biomedical use by Aubrey de Grey in 2000 [98] and successfully applied to human cells for the first time in 2002 as described in two papers. Manfredi et al. demonstrated the rescue of a deficiency in ATP synthesis by transfer of the mitochondrial ATP6 gene to the nucleus [99]. Guy et al. allotopically expressed the mitochondrial ND4 subunit gene of complex I, which was also the first point mutation in the mitochondrial genome linked to Leber's Hereditary Optic Neuropathy [100]. The latter approach advanced in 2018 to clinical Phase I, II and III trials (reviewed in [101]). The authors of these studies found an improvement in vision when they injected the viral vector carrying a modified ND4 gene into only one eye while using the other eye as a control for disease progression [102, 103].

\subsection{Mitochondrial transplantation}

A review paper published in August 2020 asked the question "if (can)... transplant(ing) fully functional mitochondria directly into defective cells (to treat mitochondrial disorders). Could this be too good to be true?" [104]. Two years earlier, a paper carried the headline "Mitochondrial transplantation in humans: "magical" cure or cause for concern?" [105]. Both of these papers mirror the skepticism with which many reports claiming the effective transplantation of mitochondria into cells, tissues and patients have been met. The paper from August 2020 states

"... all these data (about effective mitochondrial transplantation) challenge our understanding of how organelles behave in cells, and we should consequently demand high levels of rigour to support these claims" [104].

It comes to mind that Laplace once said "the weight of evidence for an extraordinary claim must be proportional to its strangeness", which much later was rephrased by Carl Sagan (1934-1996), into "extraordinary claims require extraordinary evidence" [106].

It is not our aim here to investigate exactly how extraordinary all those claims are, we just want to briefly outline the history of mitochondrial transplantation. First of all, to anyone who believes in Lynn Petra Margulis' (19382011) (1967 Lynn Sagan) endosymbiotic theory of the origin of eukaryotic cells [2] it should not come as a total surprise that mammalian cells might have the ability to internalize exogenous mitochondria considering that their progenitor (prokaryotic) cells must have had that ability. However, experimental evidence was lacking until the beginning of the 1980s, when two papers provided data in support of a cells ability to internalize exogenous mitochondria [107, 108]. Both of these papers apparently fell into oblivion, because a 2006 PNAS paper [109] was asking the question whether cells with nonfunctional mitochondria could be repaired by transfer of functional mitochondria without referencing them. The authors answered their own question by demonstrating data which led them to 
conclude that mitochondrial transfer between cells can rescue aerobic respiration [109] though the exact mechanism of mitochondrial transfer was left open. This reported mitochondrial transfer between cells however was immediately doubted in the same year by Csordas who wrote that "these results do not establish whether it was only mtDNA or whole functional mitochondria that were transferred' [110].

During the same period one of us (VW) conducted his own investigations in collaboration with Keshav Singh's laboratory and we were able to demonstrate that xenogeneic transfer of murine mitochondria into human cells lacking functional mitochondria can, for a limited time, functionally restore respiration in cells lacking mtDNA [111]. Two years later, in 2009, James McCully and his team at the Harvard Institute of Medicine tested the hypothesis whether transplantation of mitochondria isolated from remote tissue unaffected by ischemia into the ischemic zone before reperfusion could enhance cellular viability during reperfusion. They succeeded in showing that injection of respirationcompetent mitochondria could significantly decrease infarct size in a surgical ischemia/reperfusion model [112]. Subsequently, McCully's group published a series of papers validating their approach [113-123] and several other groups, using different clinical models, followed [124-127]. In conclusion we believe that it is certainly justified to keep demanding "high levels of rigor to support all data" [104] but we are not so sure whether implying the involvement of "magic" for mitochondrial transplantation [105] is appropriate.

\section{Gene replacement - The " 3 Parent Baby"}

Tremendous success has been achieved in recent years in trying to avoid pathogenic mtDNA transmission between generations via so-called mitochondrial replacement therapy (MRT), which involves several different reproductive technologies designed to replace the mitochondria in eggs from affected women. This revolutionary approach to essentially stop the maternally transmission of defect mtDNA to their newborns was pioneered at Newcastle University [128-130]. The children born by utilizing this approach will have nuclear DNA from both parents and healthy mtDNA from another woman as a third person, hence the term "3 Parent Baby". Currently, an ongoing clinical trial in the UK is designed to assess the outcome of such mitochondrial donation from a healthy woman to a woman carrying mtDNA mutations on the first 75 children born [92].

\section{Mitochondrial MicroRNAs (mitomiRs)}

MicroRNAs (miRNAs) are noncoding RNA molecules containing between 18 and 25 nucleotides which act generally as post-transcriptional regulators of gene expression via pairing with complementary mRNA thereby affecting multiple cellular processes like cell growth, proliferation, differentiation, embryonic development and apoptosis [131]. The first miRNA (not mitochondrial!) was discovered in the early 1990s in C. elegans [132] and miRNAs were recognized as a new specific group of biological regulators by the early 2000's [133-136]. As of 2015, approximately
600 human microRNAs have been identified [137]. The existence of microRNA in mitochondria, termed "mitomiR" was established between 2009 and 2012 [138-143]. This new field of mitochondrial microRNAs is currently flourishing. Our 11th World Congress on Targeting Mitochondria held virtually on October 29-30, 2020 dedicated an entire session to the role of non-coding RNAs in the nuclearmitochondrial cross talk and their potential application for RNA medicine (https://www.targeting-mitochondria.com). The major focus on current mitomiR research lies on elucidating the mechanistic details of the transport of microRNAs from the nucleus into mitochondria, on exploring the possibility of mitochondrial genome generated microRNAs and on trying to understand how mitomiRs regulate mitochondrial gene expression, mitochondrial biogenesis and mitochondrial functions [131].

\section{Conclusion}

In 2001 one of us (VW) wrote in the preface for a Theme Issue about "Drug and DNA delivery to mitochondria" that "the field of mitochondria is currently one of the fastest growing discipline in biomedicine" [144]. This statement from 20 years ago was made perhaps a bit prematurely, considering the remarkable progress the field of mitochondrial medicine has made during the last two decades. In Part II of our review we will continue to outline and highlight most recent developments in mitochondrial research.

\section{Abbreviations}

$\begin{array}{ll}\text { BBB } & \text { Blood Brain Barrier } \\ \text { BN-PAGE } & \text { Blue-Native Polyacrylamide Gel } \\ & \text { Electrophoresis } \\ \text { C. elegans } & \text { Caenorhabditis elegans } \\ \text { Cas9 } & \text { Caspase 9 } \\ \text { CNS } & \text { Central Nervous System } \\ \text { CRISPR } & \text { Clustered Regularly Interspaced Short } \\ & \text { Palindromic Repeats } \\ \text { GFP } & \text { Green Fluorescence Protein } \\ \text { IMM } & \text { Inner Mitochondrial Membrane } \\ \text { IMS } & \text { Intermembrane Space } \\ \text { MICOS } & \text { Mitochondrial contact site and Cristae } \\ \text { mtDNA } & \text { Organization System } \\ \text { NAD } & \text { Mitochondrial DNA } \\ \text { OPA 1 } & \text { Nicotinamide Adenine Dinucleotide } \\ \text { OXPHOS-ETC } & \text { Oxidative Phosphorylation Electron } \\ \text { TCA } & \text { Transfer Chain } \\ \text { tRNA } & \text { Tricarboxylic Acid }\end{array}$

\section{Conflict of interest}

Volkmar Weissig is Senior Board member at Life Sciences-Medicine of 4open, published by EDP Sciences. 
Both authors did not take any action to influence the standard submission or peer-review processes and reports no conflict of interest. The authors alone are responsible for the content and writing of this manuscript. This manuscript contains original material that has been previously published and is appropriately cited. The authors have no conflicts of interest to declare.

\section{Acknowledgments}

The authors would like to thank all members of the World Mitochondrial Society (Paris, France) for their strong support of and for their active participation in our annual World Conference of Targeting Mitochondria series. The authors would also like to thank Thomas Splettstoesser (https://www.scistyle.com) for the creation of Figures 1-3.

\section{References}

1. Margulis L (1996), Gaia is a tough bitch, Chapter 7, page 129-151, in: J. Brockman (Ed.), Third Culture: Beyond the Scientific Revolution, Simon and Schuster, Touchstone, Rockefeller Center, New York. ISBN: 0-684-80359-3.

2. Sagan L (1967), On the origin of mitosing cells. J Theor Biol 14, 3, 225-274. https://doi.org/10.1016/0022-5193(67) 90079-3.

3. Giles RE, Blanc H, Cann HM, Wallace DC (1980), Maternal inheritance of human mitochondrial DNA. Proc Natl Acad Sci USA 77, 11, 6715-6719. https://doi.org/10.1073/pnas.77. 11.6715 .

4. Luo S, Valencia CA, Zhang J, Lee NC, Slone J, Gui B, Wang X, Li Z, Dell S, Brown J, Chen SM, Chien YH, Hwu WL, Fan PC, Wong LJ, Atwal PS, Huang T (2018), Biparental inheritance of mitochondrial DNA in humans. Proc Natl Acad Sci USA 115, 51, 13039-13044. https://doi. org/10.1073/pnas.1810946115.

5. Rius R, Cowley MJ, Riley L, Puttick C, Thorburn DR, Christodoulou J (2019), Biparental inheritance of mitochondrial DNA in humans is not a common phenomenon. Genet Med 12, 2823-2826. https://doi.org/10.1038/s41436019-0568-0.

6. Lutz-Bonengel S, Parson W (2019), No further evidence for paternal leakage of mitochondrial DNA in humans yet. Proc Natl Acad Sci USA 116, 1821-1822. https://doi.org/ 10.1073 /pnas. 1820533116 .

7. Luft R, Ikkos D, Palmieri G, Ernster L, Afzelius B (1962), A case of severe hypermetabolism of nonthyroid origin with a defect in the maintenance of mitochondrial respiratory control: a correlated clinical, biochemical, and morphological study. J Clin Invest 41, 1776-1804. https://doi.org/ 10.1172/JCI104637.

8. Wallace DC, Singh G, Lott MT, Hodge JA, Schurr TG, Lezza AM, Elsas LJ 2nd, Nikoskelainen EK (1988), Mitochondrial DNA mutation associated with Leber's hereditary optic neuropathy. Science 242, 1427-1430. https://doi.org/ 10.1126 /science.3201231.

9. Edeas M, Weissig V (2013), Targeting mitochondria: strategies, innovations and challenges: The future of medicine will come through mitochondria. Mitochondrion 13, 389-390. https://doi.org/10.1016/j.mito.2013.03.009.

10. Tzagoloff A (1982), Mitochondria, Plenum Press, New York. ISBN 0-306-40799-X.
11. Altmann R (1890), Die Elementarorganismen und ihre Beziehungen zu den Zellen, 1. Auflage, Von Veit \& Comp Verlag, Leipzig. Deutsches Textarchiv. https://www. deutschestextarchiv.de/altmann elementarorganismen 1890/9. Access: April 9, 2021.

12. Benda C (1898), Ueber die Spermatogenese der Vertebraten und höherer Evertebraten, II. Theil: Die Histiogenese der Spermien. Archiv Anatomie und Physiologie 73, 393-398.

13. Chan DC (2006), Mitochondrial fusion and fission in mammals. Annu Rev Cell Dev Biol 22, 79-99. https://doi. org/10.1146/annurev.cellbio.22.010305.104638.

14. Chen H, Chan DC (2005), Emerging functions of mammalian mitochondrial fusion and fission. Hum Mol Genet 14, 2, R283-R289. https://doi.org/10.1093/hmg/ddi270.

15. Griffin EE, Graumann J, Chan DC (2005), The WD40 protein Caf4p is a component of the mitochondrial fission machinery and recruits Dnm1p to mitochondria. J Cell Biol 170, 237-248. https://doi.org/10.1083/jcb.200503148.

16. Palade GE (1952), The fine structure of mitochondria. Anat Rec 114, 427-451. https://doi.org/10.1002/ar. 1091140304.

17. Palade GE (1953), An electron microscope study of the mitochondrial structure. J Histochem Cytochem 1, 188-211. https://doi.org/10.1177/1.4.188.

18. Calvo SE, Mootha VK (2010), The mitochondrial proteome and human disease. Annu Rev Genomics Hum Genet. 11, 25-44. https://doi.org/10.1146/annurev-genom-082509141720 .

19. Koopman W (2019), Viscosity and macromolecular crowding affects size-dependent protein diffusion and conformation in the mitochondrial matrix, University of Cambridge, MRC Mitochondrial Biology Unit Seminars. http://talks.cam.ac.uk/talk/index/120409 (accessed March 15, 2021)

20. Perkins GA, Renken CW, Song JY, Frey TG, Young SJ, Lamont S, Martone ME, Lindsey S, Ellisman MH (1997), Electron tomography of large, multicomponent biological structures. J Struct Biol 120, 219-227. https://doi.org/ 10.1006/jsbi.1997.3920.

21. Perkins GA, Song JY, Tarsa L, Deerinck TJ, Ellisman MH, Frey TG (1998), Electron tomography of mitochondria from brown adipocytes reveals crista junctions. J Bioenerg Biomembr 30, 5, 431-442. https://doi.org/10.1023/a: 1020586012561.

22. Kondadi AK, Anand R, Reichert AS (2019), Functional interplay between cristae biogenesis, mitochondrial dynamics and mitochondrial DNA integrity. Int J Mol Sci 20, 17 , 4311. https://doi.org/10.3390/ijms20174311.

23. Hackenbrock CR (1966), Ultrastructural bases for metabolically linked mechanical activity in mitochondria. I. Reversible ultrastructural changes with change in metabolic steady state in isolated liver mitochondria. J Cell Biol 30, 2, 269-297. https://doi.org/10.1083/jcb.30.2.269.

24. Hackenbrock CR (1968), Chemical and physical fixation of isolated mitochondria in low-energy and high-energy states. Proc Natl Acad Sci USA 61, 2, 598-605. https://doi.org/ 10.1073/pnas.61.2.598

25. Hackenbrock CR (1968), Ultrastructural bases for metabolically linked mechanical activity in mitochondria. II. Electron transport-linked ultrastructural transformations in mitochondria. J Cell Biol 37, 2, 345-369. https://doi.org/ 10.1083/jcb.37.2.345.

26. Scorrano L, Ashiya M, Buttle K, Weiler S, Oakes SA, Mannella CA, Korsmeyer SJ (2002), A distinct pathway remodels mitochondrial cristae and mobilizes cytochrome c during apoptosis. Dev Cell 2, 1, 55-67. https://doi.org/ 10.1016/s1534-5807(01)00116-2. 
27. Otto AM (2016), Warburg effect(s)-a biographical sketch of Otto Warburg and his impacts on tumor metabolism. Cancer Metab 4, 5. https://doi.org/10.1186/s40170-016-0145-9.

28. Mac Munn CA (1886), Researches on Myohaematin and the Histohaematins. Philos Trans R Soc Lond 177, 267-298.

29. Keilin D (1925), On cytochrome, a respiratory pigment, common to animals, yeast, and higher plants. Proc. R. Soc. Lond. 98, 312-339.

30. Krebs HA, Johnson WA (1937), Metabolism of ketonic acids in animal tissues. Biochem $\mathrm{J}$ 31, 4, 645-660. https://doi.org/10.1042/bj0310645.

31. Krebs HA (1937), Dismutation of pyruvic acid in Gonococcus and Staphylococcus. Biochem J 31, 4, 661-671. https://doi. org/10.1042/bj0310661.

32. Krebs HA (1937), The intermediate metabolism of carbohydrates. Lancet 2, 736-738.

33. Krebs HA (1937), The role of fumarate in the respiration of Bacterium coli commune. Biochem J 31, 11, 2095-2124. https://doi.org/10.1042/bj0312095.

34. Krebs HA, Johnson WA (1937), Acetopyruvic acid (ay-diketovaleric acid) as an intermediate metabolite in animal tissues. Biochem J 31, 5, 772-779. https://doi.org/ 10.1042/bj0310772.

35. Roskoski R (2018), Adenosine Triphosphate (ATP). AccessScience, McGraw-Hill. https://doi.org/10.1036/10978542.010700 .

36. Kalckar H (1937), The significance of phosphorylation in kidney tissue. Skand Arch Physiol 77, 46-47.

37. Belitser VA, Tsibakova ET (1939), The mechanism of phosphorylation associated with respiration. Biokhimiia 4, 516-535.

38. Lipmann F (1939), Role of phosphate in pyruvic acid dehydrogenation. Nature 144, 381-382.

39. Lipmann F (1940), A phosphorylated oxidation product of pyruvic acid. J Biol Chem 134, 463-464.

40. Lipmann F (1941), Metabolic generation and utilization of phosphate bond energy. Adv Enzymol Rel S Bi 1, 99-162.

41. Slater EC, Holton FA (1953), Oxidative phoshorylation coupled with the oxidation of alpha-ketoglutarate by heartmuscle sarcosomes. 1. Kinetics of the oxidative phosphorylation reaction and adenine nucleotide specificity. Biochem Jl 55, 3, 530-544. https://doi.org/10.1042/bj0550530.

42. Slater EC (1953), Mechanism of phosphorylation in the respiratory chain. Nature 172, 4387, 975-978. https://doi. org $/ 10.1038 / 172975 \mathrm{a} 0$.

43. Siekevitz P (1957), Powerhouse of the cell. Scientific American 197, 131-144.

44. Williams RJ (1961), Possible Functions of chains of catalysts. J Theor Biol 11-17, 1961. https://doi.org/ 10.1016/0022-5193(61)90023-6.

45. Mitchell P (1961), Coupling of phosphorylation to electron and hydrogen transfer by a chemi-osmotic type of mechanism. Nature 191, 144-148. https://doi.org/10.1038/191144a0.

46. Mitchell P (1961), Conduction of protons through membranes of mitochondria and bacteria by uncouplers of oxidative phosphorylation. Biochem J 81, 1, P24. ISSN: 0264-6021.

47. Mitchell P (1961), Chemiosmotic coupling in oxidative and photosynthetic phosphorylation. Biochem J 79, 3, P23. ISSN:0264-6021.

48. Hatefi Y, Haavik AG, Griffiths DE (1962), Studies on electron transfer system. 41. Reduced coenzyme Q (Qh2)Cytochrome C reductase. J Biol Chem 237, 1681-1685. PMID: 13905328.

49. Fowler LR, Richardson SH, Hatefi Y (1962), A rapid method for preparation of highly purified cytochrome oxidase. Bioch Biophys Acta 64, 170-173. https://doi.org/ 10.1016/0006-3002(62)90770-9.
50. Hatefi Y, Haavik AG, Fowler LR, Griffiths DE (1962), Studies on electron transfer system. Reconstitution of electron transfer system. J Biol Chem 237, 2661-2669PMID: 13905326.

51. Hatefi Y, Haavik AG, Griffiths DE (1962), Studies on electron transfer system. Preparation and properties of mitochondrial Dpnh-Coenzyme Q reductase. J Biol Chem 237, 1676-1680. PMID: 13905327.

52. Hochli M, Hackenbrock CR (1976), Fluidity in mitochondrial-membranes - thermotropic lateral translational motion of intramembrane particles. Proc Natl Acad Sci USA 73, 5, 1636-1640. https://doi.org/10.1073/pnas.73.5.1636.

53. Hackenbrock CR, Höchli M, Chau RM (1976), Calorimetric and freeze fracture analysis of lipid phase-transitions and lateral translational motion of intramembrane particles in mitochondrial membranes. Biochim Biophys Acta 455, 2, 466-484. https://doi.org/10.1016/0005-2736(76)90318-7.

54. Schagger H, Pfeiffer K (2000), Supercomplexes in the respiratory chains of yeast and mammalian mitochondria. EMBO Jl 19, 1777-1783. https://doi.org/10.1093/emboj/ 19.8.1777.

55. Dudkina NV, Kouril R, Peters K, Braun HP, Boekema EJ (2010), Structure and function of mitochondrial supercomplexes. Biochim Biophys Acta 1797, 664-670. https://doi. org/10.1016/j.bbabio.2009.12.013.

56. Gu J, Wu M, Guo R, Yan K, Lei J, Gao N, Yang M (2016), The architecture of the mammalian respirasome. Nature 537, 639-643. https://doi.org/10.1038/nature19359.

57. Lenaz G, Genova ML (2010), Structure and organization of mitochondrial respiratory complexes: a new understanding of an old subject. Antioxid Redox Signal 12, 961-1008. https://doi.org/10.1089/ars.2009.2704.

58. Guo R, Gu J, Wu M, Yang M (2016), Amazing structure of respirasome: unveiling the secrets of cell respiration. Protein Cell 7, 854-865. https://doi.org/10.1007/s13238-016-0329-7.

59. Luft R (1994), The development of mitochondrial medicine. Proc Natl Acad Sci USA 91, 19, 8731-8738. https://doi. org/10.1073/pnas.91.19.8731.

60. Holt IJ, Harding AE, Morgan-Hughes JA (1988), Deletions of muscle mitochondrial DNA in patients with mitochondrial myopathies. Nature 331, 717-719. https://doi.org/ $10.1038 / 331717 \mathrm{a} 0$.

61. Nass MM, Nass S (1963), Intramitochondrial fibers with DNA characteristics. I. Fixation and electron staining reactions. J Cell Biol 19, 593-611. https://doi.org/10.1083/ jcb.19.3.593.

62. Anderson S, Bankier AT, Barrell BG, de Bruijn MH, Coulson AR, Drouin J, Eperon IC, Nierlich DP, Roe BA, Sanger F, Schreier PH, Smith AJ, Staden R, Young IG (1981), Sequence and organization of the human mitochondrial genome. Nature 290, 457-465. https://doi.org/ 10.1038/290457a0.

63. Elmore S (2007), Apoptosis: a review of programmed cell death. Toxicol Pathol 35, 4, 495-516. https://doi.org/ 10.1080/01926230701320337.

64. Brown GC, Nicholls DG, Cooper CE (Eds.) (1999), Mitochondria and cell death, Princeton University Press. ISBN: 0-691-05026-0.

65. Seibel P, Trappe J, Villani G, Klopstock T, Papa S, Reichmann H (1995), Transfection of mitochondria: strategy towards a gene therapy of mitochondrial DNA diseases. Nucleic Acids Res 23, 10-17. https://doi.org/10.1093/nar/ 23.1.10.

66. Weissig V, Lasch J, Erdos G, Meyer HW, Rowe TC, Hughes J (1998), DQAsomes: a novel potential drug and gene delivery system made from Dequalinium. Pharm Res 15, 334-337. https://doi.org/10.1023/a:1011991307631. 
67. Weissig V (2011), From serendipity to mitochondriatargeted nanocarriers. Pharm Res 28, 11, 2657-2668. https://doi.org/10.1007/s11095-011-0556-9.

68. Felgner PL, Gadek TR, Holm M, Roman R, Chan HW, Wenz M, Northrop JP, Ringold GM, Danielsen M (1987), Lipofection: a highly efficient, lipid-mediated DNA-transfection procedure. Proc Natl Acad Sci USA 84, 21, 74137417. https://doi.org/10.1073/pnas.84.21.7413.

69. Weissig V, Torchilin VP (2001), Cationic bolasomes with delocalized charge centers as mitochondria-specific DNA delivery systems. Adv Drug Deliv Rev 49, 1-2, 127-149. https://doi.org/10.1016/s0169-409x(01)00131-4.

70. Weissig V, Torchilin VP (2001), Towards mitochondrial gene therapy: DQAsomes as a strategy. J Drug Targeting 9, 1, 1-13. https://doi.org/10.3109/10611860108995628.

71. Lasch J, Meye A, Taubert H, Koelsch R, Mansa-ard J, Weissig V (1999), Dequalinium vesicles form stable complexes with plasmid DNA which are protected from DNase attack. Biol Chem 380, 6, 647-652. https://doi.org/ 10.1515/BC.1999.080.

72. Weissig V, D'Souza GG, Torchilin VP (2001), DQAsome/ DNA complexes release DNA upon contact with isolated mouse liver mitochondria. J Control Release 75, 3, 401-408. https://doi.org/10.1016/s0168-3659(01)00392-3.

73. D'Souza GG, Rammohan R, Cheng SM, Torchilin VP, Weissig V (2003), DQAsome-mediated delivery of plasmid DNA toward mitochondria in living cells. J Control Release 92, 1-2, 189-197. https://doi.org/10.1016/s0168-3659(03) 00297-9.

74. Weissig V, Lizano C, Torchilin VP (2000), Selective DNA release from DQAsome/DNA complexes at mitochondrialike membranes. Drug Delivery 7, 1, 1-5. https://doi.org/ 10.1080/107175400266722.

75. D'Souza GG, Boddapati SV, Weissig V (2005), Mitochondrial leader sequence-plasmid DNA conjugates delivered into mammalian cells by DQAsomes co-localize with mitochondria. Mitochondrion 5, 5, 352-358. https://doi.org/ 10.1016/j.mito.2005.07.001.

76. Lyrawati D, Trounson A, Cram D (2011), Expression of GFP in the mitochondrial compartment using DQAsomemediated delivery of an artificial mini-mitochondrial genome. Pharm Res 28, 11, 2848-2862. https://doi.org/ 10.1007/s11095-011-0544-0.

77. Bae Y, Jung MK, Song SJ, Green ES, Lee S, Park HS, Jeong SH, Han J, Mun JY, Ko KS, Choi JS (2017), Functional nanosome for enhanced mitochondria-targeted gene delivery and expression. Mitochondrion 37, 27-40. https://doi. org/10.1016/j.mito.2017.06.005.

78. Weissig V, Lozoya M, Yu N, D'Souza GGM (2021), DQAsomes as the prototype of mitochondria-targeted pharmaceutical nanocarriers: An Update. Methods Mol Biol, in press.

79. Yamada Y, Akita H, Kamiya H, Kogure K, Yamamoto T, Shinohara Y, Yamashita K, Kobayashi H, Kikuchi H, Harashima H (2008), MITO-Porter: A liposome-based carrier system for delivery of macromolecules into mitochondria via membrane fusion. Biochim Biophysi Acta 1778, 2, 423-432. https://doi.org/10.1016/j.bbamem.2007.11.002.

80. Yamada Y, Furukawa R, Yasuzaki Y, Harashima H (2011), Dual function MITO-Porter, a nano carrier integrating both efficient cytoplasmic delivery and mitochondrial macromolecule delivery. Mol Ther 19, 8, 1449-1456. https://doi. org $/ 10.1038 / \mathrm{mt} .2011 .99$.

81. Kawamura E, Maruyama M, Abe J, Sudo A, Takeda A, Takada S, Yokota T, Kinugawa S, Harashima H, Yamada Y (2020), Validation of gene therapy for mutant mitochondria by delivering mitochondrial RNA using a MITO-Porter. Mol
Ther Nucleic Acids 20, 687-698. https://doi.org/10.1016/j. omtn.2020.04.004.

82. Schatz G (1998), Protein transport. The doors to organelles. Nature 395, 6701, 439-440. https://doi.org/10.1038/26620.

83. Koehler CM, Jarosch E, Tokatlidis K, Schmid K, Schweyen RJ, Schatz G (1998), Import of mitochondrial carriers mediated by essential proteins of the intermembrane space. Science 279, 5349, 369-373. https://doi.org/10.1126/science. 279.5349.369

84. Kaldi K, Neupert W (1998), Protein translocation into mitochondria. BioFactors 8, 3-4, 221-224. https://doi.org/ 10.1002/biof.5520080308.

85. Entelis NS, Kolesnikova OA, Martin RP, Tarassov IA (2001), RNA delivery into mitochondria. Adv Drug Deliv Rev 49, 1-2, 199-215. https://doi.org/10.1016/s0169-409x (01)00135-1.

86. Schneider A (1994), Import of RNA into mitochondria. Trends Cell Biol 4, 8, 282-286. https://doi.org/10.1016/ 0962-8924(94)90218-6.

87. Entelis NS, Krasheninnikov IA, Martin RP, Tarassov IA (1996), Mitochondrial import of a yeast cytoplasmic tRNA (Lys): possible roles of aminoacylation and modified nucleosides in subcellular partitioning. FEBS Lett 384, 1, 38-42. https://doi.org/10.1016/0014-5793(96)00259-1.

88. Tarassov IA, Martin RP (1996), Mechanisms of tRNA import into yeast mitochondria: an overview. Biochimie 78, 6, 502-510. https://doi.org/10.1016/0300-9084(96)84756-0.

89. Jeandard D, Smirnova A, Tarassov IA, Barrey E, Smirnov A, Entelis N (2019), Import of non-coding rnas into human mitochondria: A critical review and emerging approaches. Cells 8, 3, 286. https://doi.org/10.3390/cells8030286.

90. Loutre R, Heckel AM, Smirnova A, Entelis N, Tarassov I (2018), Can mitochondrial DNA be CRISPRized: Pro and contra. IUBMB Life 70, 12, 1233-1239. https://doi.org/ 10.1002 iub.1919.

91. Taylor RW, Chinnery PF, Turnbull DM, Lightowlers RN (1997), Selective inhibition of mutant human mitochondrial DNA replication in vitro by peptide nucleic acids. Nat Genet 15, 2, 212-215. https://doi.org/10.1038/ng0297212.

92. Russell OM, Gorman GS, Lightowlers RN, Turnbull DM (2020), Mitochondrial diseases: hope for the future. Cell 181, 1, 168-188. https://doi.org/10.1016/j.cell.2020.02. 051.

93. Minczuk M, Papworth MA, Miller JC, Murphy MP, Klug A (2008), Development of a single-chain, quasi-dimeric zinc-finger nuclease for the selective degradation of mutated human mitochondrial DNA. Nucleic Acids Res 36, 12, 3926-3938. https://doi.org/10.1093/nar/gkn313.

94. Bacman SR, Kauppila JHK, Pereira CV, Nissanka N, Miranda M, Pinto M, Williams SL, Larsson NG, Stewart JB, Moraes CT (2018), Author correction: MitoTALEN reduces mutant mtDNA load and restores tRNA(Ala) levels in a mouse model of heteroplasmic mtDNA mutation. Nat Med 24, 12, 1940. https://doi.org/10.1038/s41591-0180234-0.

95. Bacman SR, Kauppila JHK, Pereira CV, Nissanka N, Miranda M, Pinto M, Williams SL, Larsson NG, Stewart JB, Moraes CT (2018), MitoTALEN reduces mutant mtDNA load and restores tRNA(Ala) levels in a mouse model of heteroplasmic mtDNA mutation. Nat Med 24, 11, 1696-1700. https://doi.org/10.1038/s41591-018-0166-8.

96. Law RH, Farrell LB, Nero D, Devenish RJ, Nagley P (1988), Studies on the import into mitochondria of yeast ATP Synthase subunit- 8 and subunit- 9 encoded by artificial nuclear genes. FEBS Lett 236, 2, 501-505. https://doi.org/ $10.1016 / 0014-5793(88) 80086-3$. 
97. Farrell LB, Gearing DP, Nagley P (1988), Reprogrammed expression of subunit-9 of the mitochondrial ATPase complex of Saccharomyces cerevisiae - Expression invitro from a chemically synthesized gene and import into isolated mitochondria. Eur J Biochem 173, 1, 131-137. https://doi. org $/ 10.1111 /$ j.1432-1033.1988.tb13976.x.

98. de Grey AD (2000), Mitochondrial gene therapy: an arena for the biomedical use of inteins. Trends Biotechnol 18, 9, 394-399. https://doi.org/10.1016/s0167-7799(00)01476-1.

99. Manfredi G, Fu J, Ojaimi J, Sadlock JE, Kwong JQ, Guy J, Schon EA (2002), Rescue of a deficiency in ATP synthesis by transfer of MTATP6, a mitochondrial DNA-encoded gene, to the nucleus. Nat Genet 30, 4, 394-399. https://doi. org/10.1038/ng851.

100. Guy J, Qi X, Pallotti F, Schon EA, Manfredi G, Carelli V, Martinuzzi A, Hauswirth WW, Lewin AS (2002), Rescue of a mitochondrial deficiency causing Leber hereditary optic neuropathy. Ann Neurol 52, 5, 534-542. https://doi.org/ 10.1002 /ana.10354.

101. Weissig V (2020), Drug development for the therapy of mitochondrial diseases. Trends Mol Med 26, 1, 40-57. https://doi.org/10.1016/j.molmed.2019.09.002.

102. Guy J, Feuer WJ, Davis JL, Porciatti V, Gonzalez PJ, Koilkonda RD, Yuan H, Hauswirth WW, Lam BL (2017), Gene therapy for Leber Hereditary Optic Neuropathy. Ophthalmology 124, 11, 1621-1634. https://doi.org/ 10.1016/j.ophtha.2017.05.016.

103. Guy J, Koilkonda RD, Feuer WJ, Davis JL, Porciatti V, Gonzalez P, Yuan H, Lam BL (2017), Gene therapy for LHON suppresses neurodegeneration. Investigative Ophthalmology Visual Science (IVOS) 58, 4492.

104. Lightowlers RN, Chrzanowska-Lightowlers ZM, Russell OM (2020), Mitochondrial transplantation-a possible therapeutic for mitochondrial dysfunction? Mitochondrial transfer is a potential cure for many diseases but proof of efficacy and safety is still lacking. EMBO Rep 21, 9, e50964. https://doi. org/10.15252/embr.202050964.

105. Bertero E, Maack C, O'Rourke B (2018), Mitochondrial transplantation in humans: "magical" cure or cause for concern? J Clin Invest 128, 12, 5191-5194. https://doi.org/ 10.1172/JCI124944.

106. Tressoldi PE (2011), Extraordinary claims require extraordinary evidence: the case of non-local perception, a classical and bayesian review of evidences. Front Psychol 2, 117. https://doi.org/10.3389/fpsyg.2011.00117.

107. Clark MA, Shay JW (1982), Mitochondrial transformation of mammalian cells. Nature 295, 5850, 605-607. https://doi. org $/ 10.1038 / 295605 \mathrm{a} 0$.

108. Ber R, Stauver MG, Shay JW (1984), Use of isolated mitochondria to transfer chloramphenicol resistance in hamster cells. Isr J Med Sci 20, 3, 244-248. PMID: 6724871.

109. Spees JL, Olson SD, Whitney MJ, Prockop DJ (2006), Mitochondrial transfer between cells can rescue aerobic respiration. Proc Natl Acad Sci USA 103, 5, 1283-1288. https://doi.org/10.1073/pnas.0510511103.

110. Csordas A (2006), Mitochondrial transfer between eukaryotic animal cells and its physiologic role. Rejuvenation Res 9, 4, 450-454. https://doi.org/10.1089/rej.2006.9.450.

111. Katrangi E, D'Souza GGM, Boddapati SV, Kulawiec M, Singh KK, Bigger B, Weissig V (2007), Xenogenic transfer of isolated murine mitochondria into human rho0 cells can improve respiratory function. Rejuvenation Res 10, 4, 561570. https://doi.org/10.1089/rej.2007.0575.

112. McCully JD, Cowan DB, Pacak CA, Toumpoulis IK, Dayalan H, Levitsky S (2009), Injection of isolated mitochondria during early reperfusion for cardioprotection. Am
J Physiol Heart Circ Physiol 296, 1, H94-H105. https://doi. org/10.1152/ajpheart.00567.2008.

113. Guariento A, Doulamis IP, Duignan T, Kido T, Regan WL, Saeed MY, Hoganson DM, Emani SM, Fynn-Thompson F, Matte GS, Del Nido PJ, McCully JD (2020), Mitochondrial transplantation for myocardial protection in ex-situperfused hearts donated after circulatory death. J Heart Lung Transplant S1053-2498, 20, 31625-31629. https://doi. org/10.1016/j.healun.2020.06.023.

114. Doulamis IP, Guariento A, Duignan T, Kido T, Orfany A, Saeed MY, Weixler VH, Blitzer D, Shin B, Snay ER, Inkster JA, Packard AB, Zurakowski D, Rousselle T, Bajwa A, Parikh SM, Stillman IE, Del Nido PJ, McCully JD (2020), Mitochondrial transplantation by intra-arterial injection for acute kidney injury. Am J Physiol Renal Physiol 3193, F403-F413. https://doi.org/10.1152/ ajprenal.00255.2020.

115. Doulamis IP, Guariento A, Duignan T, Orfany A, Kido T, Zurakowski D, Del Nido PJ, McCully JD (2020), Mitochondrial transplantation for myocardial protection in diabetic hearts. Eur J Cardiothorac Surg 57, 5, 836-845. https://doi.org/10.1093/ejcts/ezz326.

116. Moskowitzova K, Orfany A, Liu K, Ramirez-Barbieri G, Thedsanamoorthy JK, Yao R, Guariento A, Doulamis IP, Blitzer D, Shin B, Snay ER, Inkster JHA, Iken K, Packard AB, Cowan DB, Visner GA, Del Nido PJ, McCully JD (2020), Mitochondrial transplantation enhances murine lung viability and recovery after ischemia-reperfusion injury. Am J Physiol Lung Cell Mol Physiol 318, 1, L78-L88. https://doi.org/10.1152/ajplung.00221.2019.

117. Orfany A, Arriola CG, Doulamis IP, Guariento A, RamirezBarbieri G, Moskowitzova K, Shin B, Blitzer D, Rogers C, Del Nido PJ, McCully JD (2020), Mitochondrial transplantation ameliorates acute limb ischemia. J Vasc Surg 71, 3, 1014-1026. https://doi.org/10.1016/j.jvs.2019.03.079.

118. Emani SM, McCully JD (2018), Mitochondrial transplantation: applications for pediatric patients with congenital heart disease. Transl Pediatr 7, 2, 169-175. https://doi.org/ 10.21037/tp.2018.02.02.

119. Cowan DB, Yao R, Thedsanamoorthy JK, Zurakowski D, Del Nido PJ, McCully JD (2017), Transit and integration of extracellular mitochondria in human heart cells. Sci Rep 7, 1, 17450. https://doi.org/10.1038/s41598-017-17813-0.

120. Emani SM, Piekarski BL, Harrild D, Del Nido PJ, McCully JD (2017), Autologous mitochondrial transplantation for dysfunction after ischemia-reperfusion injury. J Thorac Cardiovasc Surg 154, 1, 286-289. https://doi.org/10.1016/ j.jtcvs.2017.02.018.

121. Cowan DB, Yao R, Akurathi V, Snay ER, Thedsanamoorthy JK, Zurakowski D, Ericsson M, Friehs I, Wu Y, Levitsky S, Del Nido PJ, Packard AB, McCully JD (2016), Intracoronary delivery of mitochondria to the ischemic heart for cardioprotection. PloS One 11, 8, e0160889. https://doi.org/10.1371/journal.pone.0160889.

122. Pacak CA, Preble JM, Kondo H, Seibel P, Levitsky S, Del Nido PJ, Cowan DB, McCully JD (2015), Actin-dependent mitochondrial internalization in cardiomyocytes: evidence for rescue of mitochondrial function. Biol Open 4, 5, 622626. https://doi.org/10.1242/bio.201511478.

123. Masuzawa A, Black KM, Pacak CA, Ericsson M, Barnett RJ, Drumm C, Seth P, Bloch DB, Levitsky S, Cowan DB, McCully JD (2013), Transplantation of autologously derived mitochondria protects the heart from ischemia-reperfusion injury. Am J Physiol Heart Circ Physiol 304, 7, H966-H982. https://doi.org/10.1152/ ajpheart.00883.2012. 
124. Hayakawa K, Esposito E, Wang X, Terasaki Y, Liu Y, Xing C, Ji X, Lo EH (2016), Transfer of mitochondria from astrocytes to neurons after stroke. Nature 535, 7613, 551-555. https://doi.org/10.1038/nature18928.

125. Islam MN, Das SR, Emin MT, Wei M, Sun L, Westphalen K, Rowlands DJ, Quadri SK, Bhattacharya S, Bhattacharya J (2012), Mitochondrial transfer from bone-marrow-derived stromal cells to pulmonary alveoli protects against acute lung injury. Nat Med 18, 5, 759-765.

126. Kaza AK, Wamala I, Friehs I, Kuebler JD, Rathod RH, Berra I, Ericsson M, Yao R, Thedsanamoorthy JK, Zurakowski D, Levitsky S, Del Nido PJ, Cowan DB, McCully JD (2017), Myocardial rescue with autologous mitochondrial transplantation in a porcine model of ischemia/reperfusion. J Thorac Cardiovasc Surg 153, 4, 934-943. https://doi.org/10.1016/j.jtcvs.2016.10.077.

127. Kristensen SG, Pors SE, Andersen CY (2017), Improving oocyte quality by transfer of autologous mitochondria from fully grown oocytes. Hum Reprod 32, 4, 725-732. https://doi.org/10.1093/humrep/dex043.

128. Herbert M, Turnbull D (2018), Progress in mitochondrial replacement therapies. Nat Rev Mol Cell Biol 19, 2, 71-72. https://doi.org/10.1038/nrm.2018.3.

129. Herbert M, Turnbull D (2015), Mitochondrial replacement to prevent the transmission of mitochondrial DNA disease. EMBO Rep 16, 5, 539-540. https://doi.org/10.15252/ embr.201540354.

130. Chinnery PF, Craven L, Mitalipov S, Stewart JB, Herbert M, Turnbull DM (2014), The challenges of mitochondrial replacement. PLoS Genet 10, 4, e1004315. https://doi.org/ 10.1371/journal.pgen.1004315.

131. John A, Kubosumi A, Reddy PH (2020), Mitochondrial MicroRNAs in aging and neurodegenerative diseases. Cells 9, 6, 1345. https://doi.org/10.3390/cells9061345.

132. Lee RC, Feinbaum RL, Ambros V (1993), The C-Elegans heterochronic gene Lin-4 encodes small RNAs with antisense complementarity to Lin-14. Cell 75, 5, 843-854. https://doi.org/10.1016/0092-8674(93)90529-y.

133. Pasquinelli AE, Reinhart BJ, Slack F, Martindale MQ, Kuroda MI, Maller B, Hayward DC, Ball EE, Degnan B, Müller P, Spring J, Srinivasan A, Fishman M, Finnerty J, Corbo J, Levine M, Leahy P, Davidson E, Ruvkun G (2000), Conservation of the sequence and temporal expression of let-7 heterochronic regulatory RNA. Nature 408, 6808, 86-89. https://doi.org/10.1038/35040556.

134. Reinhart BJ, Slack FJ, Basson M, Pasquinelli AE, Bettinger JC, Rougvie AE, Horvitz HR, Ruvkun G (2000), The 21-nucleotide let-7 RNA regulates developmental timing in
Caenorhabditis elegans. Nature 403, 6772, 901-906. https://doi.org/10.1038/35002607.

135. Lagos-Quintana M, Rauhut R, Lendeckel W, Tuschl T (2001), Identification of novel genes coding for small expressed RNAs. Science 294, 5543, 853-858. https://doi. org/10.1126/science.1064921.

136. Lau NC, Lim LP, Weinstein EG, Bartel DP (2001), An abundant class of tiny RNAs with probable regulatory roles in Caenorhabditis elegans. Science 294, 5543, 858-862. https://doi.org/10.1126/science.1065062.

137. Fromm B, Billipp T, Peck LE, Johansen M, Tarver JE, King BL, Newcomb JM, Sempere LF, Flatmark K, Hovig E, Peterson KJ (2015), A uniform system for the annotation of vertebrate microRNA genes and the evolution of the human microRNAome. Annu Rev Genet 49, 213-242. https://doi. org/10.1146/annurev-genet-120213-092023.

138. Barrey E, Saint-Auret G, Bonnamy B, Damas D, Boyer O, Gidrol X (2011), Pre-microRNA and mature microRNA in human mitochondria. PloS One 6, 5, e20220. https://doi. org/10.1371/journal.pone.0020220.

139. Bandiera S, Rüberg S, Girard M, Cagnard N, Hanein S, Chrétien D, Munnich A, Lyonnet S, Henrion-Caude A (2011), Nuclear outsourcing of RNA interference vomponents to human mitochondria. PloS One 6, 6, e20746. https://doi.org/10.1371/journal.pone.0020746.

140. Das S, Ferlito M, Kent OA, Fox-Talbot K, Wang R, Liu D, Raghavachari N, Yang Y, Wheelan SJ, Murphy E, Steenbergen C (2012), Nuclear miRNA regulates the mitochondrial genome in the heart. Circ Res 110, 12, 1596-1603. https://doi.org/10.1161/CIRCRESAHA.112.267732.

141. Kren BT, Wong PYP, Sarver A, Zhang X, Zeng Y, Steer CJ (2009), microRNAs identified in highly purified liverderived mitochondria may play a role in apoptosis. RNA Biol 6, 1, 65-72. https://doi.org/10.4161/rna.6.1.7534.

142. Sripada L, Tomar D, Singh R (2012), Mitochondria: One of the destinations of miRNAs. Mitochondrion 12, 6, 593-599. https://doi.org/10.1016/j.mito.2012.10.009.

143. Sripada L, Tomar D, Prajapati P, Singh R, Singh AK, Singh R (2012), Systematic analysis of small RNAs associated with human mitochondria by deep sequencing: Detailed analysis of mitochondrial associated miRNA. PloS One 7, 9, e44873. https://doi.org/10.1371/journal.pone.0044873.

144. Weissig V, Torchilin VP (2001), Drug and DNA delivery to mitochondria. Adv Drug Deliv Rev 49, 1-2, 1-2. PMID: 11377799.

145. D'Souza GGM, Weissig V (2004), Approaches to mitochondrial gene therapy. Curr Gene Ther 4, 3, 317-328. https://doi.org/10.2174/1566523043346200. 